\section{писок літер тури}

1. орми витр $m$ льноого, м сел, м стил спеці льних рідин при експлу $m$ ції, ремонті $m$ консерв ції військової техніки й озброєння бройних ил кр їни: зб. норм т. док. - .. ( орм тивні директивні пр вові документи).

2. орми витр $m n$ лив $і$ м стильних м тері лів н втомобільному тр нспорті. 2 ред кція: зб. норм $\mathrm{m}$. док. - . „ ерж втотр нс проект”, 2004. 72 c. - ( орм тивні директивні пр вові документи).

3. оворущенко . . втомобильное топливо.. кего экономить? / . . оворущенко- рьков: ищ, школ , 1973. - $143 c$
4. рубель . . 2 тоф кторне нормув ння витр $m$ п лив повноприводних втомобілів / . . рубель // истеми озброєння і військов технік . - 2007. - № 3(11). - . 21- 24 .

5. $p$ йник . . иференційов не нормув ння витр $m n$ лив в нт жнних втомобілів / . . $p$ йник, рубель // існик онеиького інституту втомобільного тр нспорту. - 2007.-- № 3. - . 19- 24

6. еслюк. . 2 тоф кторн оцінк $n$ ливної економічності втомобілів у вз ємозв'язку з умов ми руху / . . еслюк, . . ок рь, . . рубель // втотехнік , втобуси, в нт жівки. - 2007. - №1. - . 37-43.

дійщл до ред киії 2.09.2010 p.

ецензент: доктор технічних н ук, професор . . узьо, ціон льний університет “ ьвівськ політехнік ”, ьвів.

. . рубель, . . оловий, . . ихонов

ст тье проведен н лиз р сходов топлив полноприводными грузовыми втомобилями в $з$ висимости от условий движения. помощью методики многоф кторного пл ниров ния эксперимент и использов ния полиноми льных моделей был сформиров н м трии исследов ний, в которой были з ложены ре льные условия движения. егрессионное ур внение нелинейного опис ния исследуемых процессов позволило построить топливноскоростную х р ктеристику постоянного движения втомобиля и осуществить ср внительную оценку ди $n$ зон линейных р сходов топлив втомобиля $м-4310$ н

лючевые слов : топливн я бережливость, условия движения, грузовые втомобили.

\title{
ANALYSIS OF FUEL THRIFT OF FULLDRIVE TRUCK DEPENDING ON THE TERMS OF MOTION
}

M.G. Grubel, Yu.P. Sholoviy, O.O. Tikhonov

In the article the analysis of charges of fuel is conducted by fulldrive trucks depending on the terms of motion. By the method of the multivariable planning of experiment and use of polinomial models the matrix of researches was created, on the basis of which the real terms of motion were formed. Regressive equalization of nonlinear description of the probed processes allowed to build fuel-velocity description of permanent motion of car and carry out the comparative estimation of range of linear charges of fuel of car of KAMAZ - 4310 on different types dear.

Keywords: fuel thrift, terms of motion, trucks.

623.4.017

. . ндреєв ${ }^{1}$, . . литич $^{1}$, . рв нець $^{1}$, . . гд с рян ${ }^{2}$

1 к демія сухопутних військ імені гетьм н етр г йд чного, ввів

2 ияіон льний університет оборони кр їни, иїв

озглянут методик визн чення пок зників довговічності озброєння дозволяє обгрунтув ти перегляд $m$ збільшення гр ничних норм тивних термінів експлу $m$ иї̈ озброєння.

лючові слов : гр ничний норм тивний термін експлу $m$ иї̈ озброєння, гр ничний ст н озброєння, довговічність озброєння.

\section{ступ}

ост новк проблеми. К 3 зн ч ють чисельні публік ції, зн чн кількість озброєння, яке зн ходиться в бройних ил х кр їни, вже вичерп л вст новлений ресурс т підляг $€$ вилученню з под льшої експлу т ції.

ідпр цюв ння гр ничного норм тивного терміну експлу т ції т н буття гр ничного ст ну, визн ченого в норм тивно-технічній документ ції 
( ) , є н йголовнішим ф ктором при визн ченні ступеня прид тності озброєння до бойового 3 стосув ння.

утність проблеми поляг $є$ в тім, що змін кількісно-якісної структури бройних ил кр їни, рівня професійної підготовки особового скл ду т зн чне скорочення фін нсув ння - вид тки держ вного бюджету н фін нсув ння потреб оборони з ост нні роки були зн чно менші (1,16$1,8 \%$ від рівня вст новленого коном кр їни « ро оборону кр їни» (3\% ), призвели до різкого зниження н явності спр вного

е в свою чергу вим г $є$ розробки нових підходів до рішення з вд нь підвищення бойового потенці лу бройних ил кр їни.

ст тті розгляд ються теоретичні з с ди визн чення пок зників довговічності озброєння н підст ві метод жонсон (по цензуров них вибірк х) для зр зків озброєння, які зн ходяться в експлу т ції.

ей метод може бути використ ний при визн ченні гр ничного норм тивного терміну експлу т ції, що дозволить прийм ти обгрунтов ні рішення щодо продовження терміну експлу т ції озброєння т в свою чергу сприятиме оптиміз ції витр т н його утрим ння.

н ліз ост нніх досліджень і публік цій. « ерж вн прогр м розвитку озброєння і військової техніки ( ) н період до 2015 року» передб ч є в якості одного 3 головних 3 вд нь з безпечення високих пок зників н дійності, модерніз ції т продовження термінів служби зр зків озброєння, утрим ння їх у постійному боєзд тному ст ні, що в свою чергу в сьогоденних ре ліях може бути вирішено з р хунок оптиміз ції витр т н експлу т цію озброєння.

К 3 зн чив в інтерв'ю г зеті « родн рмія» іністр оборони кр їни . жель: «..безумовно, потрібно визн чити з безпеченість основними зр зк ми озброєння і техніки підрозділів т ч стин, їх ст н, спр вність, ч стку від з г льної кількості в бойовому скл ді. отрібно орг нізув ти н лежну експлу т цію зброї т м йн » [4].

н ліз експлу т ційних х р ктеристик зн чної кількості зр зків озброєння бройних ил кр їни вк зує н те, що їх технічний ст н не дозволяе орг нізув ти їх под льшу н лежну експлу т цію.

к, більш як $60 \%$ зр зків озброєння т військової техніки зн ходиться в експлу т ції більше 15 років, 3 них потребує ремонту $84 \%$ p кетно- ртилерійського озброєння, в тому числі 55\% зенітно-р кетних комплексів [3].

комплектов ність р кетно- ртилерійським озброєнням зн чно перевищує норм тивну потребу в ньому т скл д є 229\%, у зв'язку з з кінченням терміну технічної прид тності $48 \%$ цього озброєння потребує вилучення з експлу т ції т спис ння [3].

ет ст тті. бмежене фін нсув ння бройних ил кр їни, відсутність коштів н розробку нового $\mathrm{T}$ модерніз цію існуючого озброєння створило істотні проблеми у підтримці озброєння у ст ні прид тному до бойового 3 стосув ння.

період реформув ння бройних ил кр їни н 63 х і скл д $\mathrm{x}$ н копичен зн чн кількість озброєння, яке згідно з норм тивними документ ми відпр цюв ло гр ничні норм тивні терміни експлу т ції, при цьому н буття ним гр ничного ст ну визн ченого не було вр хов не і це озброєння може бути використ не в процесі под льшої експлу т ції.

p ничні норм тивні терміни експлу т ції озброєння визн чені оложенням 120.3481977 р. т скл д ють для ртилерії, мінометів, стрілецької зброї, оптичних прил дів - 40 років; електроннооптичних т кв нтових прил дів, топоприв'язників, ст біліз торів, пунктів упр вління і н ведення, н земного обл дн ння р кетних комплексів опер тивно-т ктичного и т ктичного призн чення, протит нкових р кетних комплексів i p діолок ційних ст нцій - 25-30 років; н земного обл дн ння зенітно-р кетних комплексів - 20 років. p ничні норм тивні терміни експлу т ції решти озброєння скл д ють 40 років [1].

нструкцією 3 к тегорув ння р кетнортилерійського озброєння вст новлено, що спис ння озброєння проводиться при н бутті ним гр ничного ст ну, гр ничного бо гр ничного норм тивного терміну експлу т ції.

ким чином, прийм ючи до ув ги з зн чене в оложенні 120.3481977 р., в бройних ил х кр їни зн чн ч стин озброєння відпр цюв л вст новлений термін експлу т ції т не може бути використ н для з безпечення військ.

ет ст тті - дослідити основні чинники, які вплив ють н термін експлу т ції озброєння т обгрунтув ти н підст ві цих досліджень перегляд гр ничних норм тивних термінів експлу т ції озброєння.

\section{сновний м тері л}

озгляд ючи процес експлу т ції як зр зК озброєння, т к і окремих його скл дових ч стин $\mathrm{i}$ експлу т ційних м тері лів, необхідно звернути ув гу н т кі пок зники, як пок зники довговічності $\left(T_{p, c p} ; \quad\right.$ сл,i $)$ т збереженості з,i, які безпосередньо $\mathrm{x}$ р ктеризують н дійність т прид тність зр зК до експлу т ції.

з лежності від конструктивних особливостей комплектуючих елементів, скл дових ч стин т

( . . ндреєв, . . литич, . . рв нець, . . гд с рян 
експлу т ційних м тері лів, т кож від х р ктеру змін ї технічного т якісного ст ну вони розподіляються н три основні групи:

1. ідляг ючі зносу.

ля них норм тивною документ цією вст новлюються ресурси - середній $\left(T_{p, c p}\right)$ бо г м відсотковий $(p, \gamma)$.

\section{2. т ріючі.}

ля них вст новлюються терміни збереженості

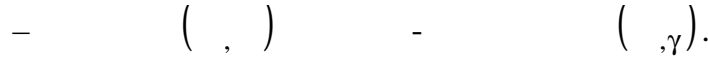

3. ідляг ючі зносу т ст ріючі одноч сно. ля них вст новлюються ресурси $(p, c p ; p, \gamma)$ т терміни служби - середній $\left(T_{p, c p}\right)$ бо г м відсотковий $(p, \gamma)$.

ерелічені пок зники довговічності т збереженості елементів є вихідними для визн чення відповідних пок зників систем (зр зків т скл дових ч стин). сі 3 зн чені пок зники довговічності можн розгляд ти як г м -відсоткові пок зники з 3 вд ною величиною $\gamma$. ри цьому величин $\gamma$ х р ктеризує вірогідність збереження пр цезд тності виробу протягом призн ченого ресурсу $(p, n p, i)$ бо терміну служби. исельні зн чення різном нітних i-х пок зників довговічності $\left(p_{p, i} ; c л, i\right)$ т збереженості $\left({ }_{3, i}\right)$ для елементів можуть бути отрим ні $з$ п спортів, , по результ т м експлу т ції зр зків т інших джерел.

рийм ючи до ув ги, що з кони розподілу ч су розподілу відмов не відомі з стосуємо методику визн чення пок зників довговічності $T_{p, c p} \mathrm{~T} \hat{p, \gamma} \hat{H}$ підст ві цензуров них вибірок.

я методик може бути використ н в процесі спостереження з вироб ми під ч с їх експлу т ції. основу методики покл дено метод жонсон (метод визн чення по цензуров них вибірк х) сутність якого поляг $€$ в н ступному:

1. изн ч ється кількість виробів, як м є бути м ксим льно великою. бір ст тистичних відомостей проводиться для не менш ніж 25 виробів, причому для з безпечення точності розр хунків число відмов в зр зк х повинн скл д ти не менше $40 \%$ від з г льного числ виробів.

поч тку збир ються $\mathrm{T}$ уз г льнюються з г льні відомості про вироби, які відобр ж ються в т бл. 1.

сі відомості для 3 повнення т кої т блиці беруться з формулярів т інших документів.

г льн $\mathbf{x}$ р ктеристик виробів

\begin{tabular}{|c|c|c|c|c|c|c|c|}
\hline \multirow{2}{*}{$\begin{array}{l}\text { № } 3 / \Pi \\
\text { (i) }\end{array}$} & \multirow[b]{2}{*}{$\begin{array}{c}\text { iк } \\
\text { виготовлення }\end{array}$} & \multicolumn{6}{|c|}{ р ктеристик експлу т ції (з формулярів) } \\
\hline & & $\begin{array}{c}\text { Км } \\
\text { пробігу }\end{array}$ & $\begin{array}{l}\text { пост- } \\
\text { ріли }\end{array}$ & $\begin{array}{c}\text { роки } \\
\mathrm{y} \\
\text { військ х }\end{array}$ & $\begin{array}{c}\text { роки } \\
\text { Н } \quad \text { збері- } \\
\text { Г нні }\end{array}$ & -2 & $\begin{array}{l}\text { мін } \\
\text { еле- } \\
\text { мен } \\
\text { тів }\end{array}$ \\
\hline 1 & 1989 & 5500 & 800 & 21 & - & $-(97,05)$ & $\begin{array}{c}\text { мін } \\
\text { Зм ЗКИ }\end{array}$ \\
\hline 2 & 1988 & 1500 & 250 & $8(88-96)$ & - & $(96)$ & - \\
\hline $\mathrm{i}$ & $\ldots$ & $\ldots$ & $\ldots$ & $\ldots$ & $\ldots$ & $\ldots$ & $\ldots$ \\
\hline
\end{tabular}

р ктеристик первинних п $\mathbf{p}$ метрів виробів

блиця 2

\begin{tabular}{|c|c|c|c|c|c|c|c|}
\hline \multirow{4}{*}{$\begin{array}{c}\text { № } \\
\text { п р } \\
\text { мет- } \\
\text { ру } \\
(\mathbf{j})\end{array}$} & \multirow{4}{*}{$\begin{array}{c}\text { р метри } \\
\text { що перевіряються } \\
\left(\mathbf{x}_{\mathbf{j}}\right)\end{array}$} & \multicolumn{6}{|c|}{ еличин п р метру } \\
\hline & & \multirow{3}{*}{$o, j$} & \multirow{3}{*}{ гр,j } & \multicolumn{4}{|c|}{$\begin{array}{rr}\text { КТИЧн } & i, j \\
\end{array}$} \\
\hline & & & & \multicolumn{4}{|c|}{ омери виробів з т блиці 1} \\
\hline & & & & 1 & 2 & 3 & $\mathrm{i}$ \\
\hline 1 & овжин 3 рядної к мори (мм) & 680 & 745 & 692 & 684 & 688 & $\ldots$ \\
\hline 2 & \begin{tabular}{|l|} 
і метр циліндр г льм \\
відк ту (мм)
\end{tabular} & 64,5 & 65 & 64,8 & 64,9 & 65,0 & $\ldots$ \\
\hline 3 & $\begin{array}{l}\text { і метр поршня г льм } \\
\text { відк ту (мм) }\end{array}$ & 64,25 & 64,2 & 64,3 & 64,1 & 64,0 & $\ldots$ \\
\hline \multirow[t]{2}{*}{4} & зор між ними (мм) & 0,25 & 0,8 & 0,5 & 0,8 & 1,0 & $\ldots$ \\
\hline & $\ldots$ & $\ldots$ & $\ldots$ & $\ldots$ & $\ldots$ & $\ldots$ & $\ldots$ \\
\hline
\end{tabular}

( ) . ндреєв, . . литич, . . рв нець, . . гд с рян 
рі ційний ряд визн чення г м -відсоткового терміну служби н підст ві цензуров ної вибірки

\begin{tabular}{|c|c|c|c|c|c|c|c|}
\hline \multirow{2}{*}{$\begin{array}{c}\text { № } \\
\text { з/П } \\
\left(N_{k}\right)\end{array}$} & \multicolumn{3}{|c|}{$\begin{array}{c}\text { ермін служби (зберіг ння) в } \\
\text { рок х }\end{array}$} & \multirow{2}{*}{$\begin{array}{c}\text { ередні } \\
\text { порядкові } \\
\text { номери } \\
\text { відмов } \\
\left(m_{i}\right)\end{array}$} & \multirow{2}{*}{$\begin{array}{c}\text { еличин } \\
\text { приросту } \\
\mathrm{m}_{\mathrm{i}} \\
\left(\Delta_{i}\right)\end{array}$} & \multicolumn{2}{|c|}{$\begin{array}{c}\text { цінк } \\
\text { вірогідності }\end{array}$} \\
\hline & $\begin{array}{c}3 \text { г льний } \\
\text { для всіх } \\
\text { N виробів } \\
\left(t_{k}\right)\end{array}$ & $\begin{array}{c}\text { до відмови } \\
\left(\mathrm{x}_{\mathrm{i}} \geq \mathrm{x}_{\text {гр }}\right) \\
\left(T_{c л, i}\right)\end{array}$ & $\begin{array}{c}\text { до } \\
\text { цензору- } \\
\text { в ння } \\
\left(\mathrm{x}_{\mathrm{i}}<\mathrm{x}_{\text {гр }}\right) \\
\left(t_{c \Omega, j}\right)\end{array}$ & & & $\begin{array}{l}\text { ідмови } \\
\left(F_{i}\right)\end{array}$ & $\begin{array}{c}\text { езвідмовної } \\
\text { роботи } \\
\left(P_{i}\right)\end{array}$ \\
\hline 1 & $\mathrm{t}_{1,1}$ & - & $\mathrm{t}_{\text {сл }, 1}$ & - & - & - & - \\
\hline 2 & $t_{2,2}$ & $\mathrm{~T}_{\text {сл, } 1}$ & - & $\mathrm{m}_{1}$ & 1 & $F_{1}$ & $P_{1}$ \\
\hline 3 & $t_{3,3}$ & $\mathrm{~T}_{\text {сл, } 2}$ & - & $\mathrm{m}_{2}$ & - & $F_{2}$ & $P_{2}$ \\
\hline 4 & $t_{4}$ & - & $\mathrm{t}_{\mathrm{слл,2}}$ & - & 2 & - & - \\
\hline 5 & $t_{5}$ & $\mathrm{~T}_{\text {сл }, 3}$ & - & $\mathrm{m}_{3}$ & - & $F_{3}$ & $P_{3}$ \\
\hline 6 & $t_{6}$ & - & $\mathrm{t}_{\text {сл, } 3}$ & - & - & - & - \\
\hline$\ldots$ & $\ldots$ & $\ldots$ & $\ldots$ & $\ldots$ & $\ldots$ & $\ldots$ & $\ldots$ \\
\hline $\mathrm{K}$ & $\mathrm{t}_{\mathrm{k}}$ & $\mathrm{T}_{\text {сл, } \mathrm{i}}$ & - & $\mathrm{m}_{\mathrm{i}}$ & - & $F_{i}$ & $P_{i}$ \\
\hline$\ldots$ & $\ldots$ & $\ldots$ & $\ldots$ & $\ldots$ & $\ldots$ & $\ldots$ & $\ldots$ \\
\hline $\mathrm{N}$ & $t_{n}$ & $\mathrm{~T}_{\text {сл, } \mathrm{r}}$ & - & $\mathrm{m}_{\mathrm{r}}$ & - & $F_{r}$ & $P_{r}$ \\
\hline
\end{tabular}

г льн х р ктеристик виробів -12

\begin{tabular}{|c|c|c|c|c|c|c|c|}
\hline \multirow[t]{2}{*}{$\begin{array}{l}\text { № 3/ח } \\
\text { (i) }\end{array}$} & \multirow{2}{*}{$\begin{array}{c}\text { ік } \\
\text { виготовлення }\end{array}$} & \multicolumn{6}{|c|}{ р ктеристик експлу т ції (з формулярів) } \\
\hline & & $\begin{array}{l}\text { знос к н лу } \\
\text { ствол (мм) }\end{array}$ & $\begin{array}{c}\text { по- } \\
\text { стріли }\end{array}$ & $\begin{array}{c}\text { роки } \\
y \\
\text { військ х }\end{array}$ & $\begin{array}{c}\text { роки } \\
\text { Н } \\
\text { збері- } \\
\text { г нні }\end{array}$ & $\begin{array}{c}\text { термін } \\
\text { екс- } \\
\text { плу т - } \\
\text { ції (p) }\end{array}$ & $\begin{array}{c}\text { технічний } \\
\text { ст н }\end{array}$ \\
\hline 1 & 1985 & 3,9 & 510 & $20(85-04)$ & $6(05-10)$ & 26 & відмов \\
\hline 2 & 1985 & 3,8 & 500 & $20(85-04)$ & $6(05-10)$ & 26 & відмов \\
\hline 3 & 1984 & 2,7 & 350 & $20(84-03)$ & $7(04-10)$ & 27 & прид тне \\
\hline 4 & 1982 & 2,3 & 300 & $20(82-01)$ & $9(02-10)$ & 29 & прид тне \\
\hline 5 & 1980 & 1,9 & 250 & $10(80-89)$ & $21(90-10)$ & 31 & прид тне \\
\hline 6 & 1978 & 1,5 & 200 & $10(78-87)$ & $23(88-10)$ & 33 & прид тне \\
\hline 7 & 1975 & 1,1 & 140 & $5(75-79)$ & $31(80-10)$ & 36 & прид тне \\
\hline 8 & 1974 & 1,0 & 130 & $5(74-78)$ & $32(79-10)$ & 37 & прид тне \\
\hline 9 & 1971 & 0,95 & 125 & $10(71-80)$ & $30(81-10)$ & 40 & прид тне \\
\hline 10 & 1971 & 0,9 & 120 & $10(71-80)$ & $30(81-10)$ & 40 & прид тне \\
\hline 11 & 1970 & 0,75 & 100 & $10(70-79)$ & $31(80-10)$ & 41 & прид тне \\
\hline
\end{tabular}

р ктеристик первинного п р метру(ді метр к н луствол) виробів -12

\begin{tabular}{|c|c|c|c|c|c|c|c|c|c|c|c|c|}
\hline \multirow{3}{*}{$0(\mathrm{MM})$} & \multirow{3}{*}{ гр } & \multicolumn{11}{|c|}{ кТичн величин } \\
\hline & & \multicolumn{11}{|c|}{ № виробів } \\
\hline & & 1 & 2 & 3 & 4 & 5 & 6 & 7 & 8 & 9 & 10 & 11 \\
\hline 100 & 103,7 & 103,9 & 103.8 & 102,7 & 102,3 & 101,9 & 101.5 & 101,1 & 100,1 & 100,95 & 100,9 & 100,75 \\
\hline
\end{tabular}


м -відсотковий термін служби виробів

$-12$

\begin{tabular}{|c|c|c|c|c|c|c|c|}
\hline \multirow[b]{2}{*}{$\begin{array}{c}\text { № } \\
\text { 3/ח } \\
\left(N_{k}\right)\end{array}$} & \multicolumn{3}{|c|}{$\begin{array}{c}\text { ермін служби (зберіг ння) в } \\
\text { рок х }\end{array}$} & \multirow[b]{2}{*}{$\begin{array}{c}\text { ередні } \\
\text { порядкові } \\
\text { номери } \\
\text { відмов } \\
\left(m_{i}\right)\end{array}$} & \multirow[b]{2}{*}{$\begin{array}{c}\text { еличин } \\
\text { приросту } \\
\mathrm{m}_{\mathrm{i}} \\
\left(\Delta_{i}\right)\end{array}$} & \multicolumn{2}{|c|}{$\begin{array}{c}\text { цінк } \\
\text { вірогідності }\end{array}$} \\
\hline & $\begin{array}{c}3 \text { г ль- } \\
\text { ний } \\
\text { для } \mathrm{N} \\
\text { виробу } \\
\left(t_{k}\right)\end{array}$ & $\begin{array}{c}\text { до відмови } \\
\left(\mathrm{x}_{\mathrm{i}} \geq \mathrm{x}_{\text {гр }}\right) \\
\left(T_{c л, i}\right)\end{array}$ & $\begin{array}{c}\text { до } \\
\text { цензо- } \\
\text { рув ння } \\
\left(\mathrm{x}_{\mathrm{i}}<\mathrm{x}_{\text {гр }}\right) \\
\left(t_{c л, j}\right)\end{array}$ & & & $\begin{array}{l}\text { ідмови } \\
\left(F_{i}\right)\end{array}$ & $\begin{array}{c}\text { езвідмовної } \\
\text { роботи } \\
\left(P_{i}\right)\end{array}$ \\
\hline 1 & 26 & 26 & - & $\mathrm{m}_{1}=1,1$ & ${ }_{0}=1,1$ & $\mathrm{~F}_{1}=0,1$ & $\mathrm{P}_{1}=0,9$ \\
\hline 2 & 26 & 26 & - & $\mathrm{m}_{2}=2,2$ & ${ }_{1}=1,1$ & $\mathrm{~F}_{2}=0,2$ & $\mathrm{P}_{2}=0,8$ \\
\hline 3 & 27 & & 27 & & & & \\
\hline 4 & 29 & & 29 & & & & \\
\hline 5 & 31 & & 31 & & & & \\
\hline 6 & 33 & & 33 & & & & \\
\hline 7 & 36 & & 36 & & & & \\
\hline 8 & 37 & & 37 & & & & \\
\hline 9 & 40 & & 40 & & & & \\
\hline 10 & 40 & & 40 & & & & \\
\hline 11 & 41 & & 41 & & & & \\
\hline
\end{tabular}

з г льних відомостях щодо експлу т ції виробів, які н д ються в дод тку до т бл. 1, дод тково вк зуються умови режимів експлу т ції, клім тичні ф ктори, умови т пр вил зберіг ння виробів у військ х, н 63 х, д ється х р ктеристик обслуговуючого персон лу, регулярність проведення оглядів, технічних обслуговув нь, кількість розбир нь і збир нь тощо.

2. ісля збору відомостей про історію кожного виробу, який досліджується, збир ються ст тистичні відомості про його п р метри. ри цьому беруться основні визн ч льні п р метри, тобто ті п р метри, які пов'яз ні із з міною грег тів т вузлів виробу бо при відпр цюв нні цього ресурсу дет ль бо елемент ст $€$ неприд тним до под льшої експлу т ції (довжин з рядної к мори, знос к н лу ствол тощо).

3. ісля збору відомостей про визн ч льні п р метри виробу збир ються ст тистичні відомості 3 х р ктеристик ми первинних визн ч льних п р метрів (т бл.2).

т тистичні відомості щодо п р метрів виробів збир ються у вигляді т блиці.

4. ісля збору відомостей про визн ч льні п р метри виробів, з зн чених в т бл. 2, проводиться визн чення пок зників їх довговічності.

ід ч с визн чення використовуються г м відсоткові терміни служби сл,ү, т терміни збереження с,, j для кожного ј-го п р метр т експлу т ційного м тері лу, н веденого в т бл.2.

підст ві відомостей, н ведених у т бл. 1, 2, скл д ється в рі ційний ряд (т бл. 3). кі т блиці скл д ються н кожні $\mathrm{j}-\mathrm{i}$ п р метри, з зн чені в гр фі 2 т блиці 2.

блиця 3 з повнюється н ступним чином:

- в гр фі 2 (термін служби 3 г льний) у н рост ючим порядку прост вляються всі терміни служби $\left(\mathrm{t}_{\mathrm{k}}\right)$ н кожний i-й виріб т нумеруються в гр фі 1 з пис ні в гр фі 2 терміни служби;

- в гр фі 3 (термін служби до відмови) 3 зн ч ються терміни служби виробів;

- в гр фу 7 з писуються перевірені п р метри досягли гр ничного зн чення $\left(\mathrm{x}_{\mathrm{i}} \geq \mathrm{x}_{\text {гр }}\right)$;

- в гр фі 4 (термін служби, при якому не відбулося відмови) 3 зн ч ються терміни служби тих виробів, у яких перевірені п р метри не досягли гр ничного зн чення $\left(\mathrm{x}_{\mathrm{i}}<\mathrm{x}_{\text {гр }}\right)$ (термін служби до цензурув ння);

- в гр фі 5 з зн ч ються зн чення середніх порядкових номерів термінів служби до відмови $\mathrm{m}_{\mathrm{i}}$, які визн ч ються $з$ формул ми

$$
\begin{array}{r}
\mathrm{m}_{\mathrm{i}}=\mathrm{m}_{\mathrm{i}-1}+\mathrm{i}-1 ; \mathrm{m}_{0}=0 \\
\Delta_{i-1}=\frac{N-m_{i-1}}{N-N_{k-1}}
\end{array}
$$

де $\mathrm{i}-1-$ приросток зн чення $\mathrm{m}_{\mathrm{i}-1}$, визн ч ється 3 формулою (2);

$\mathrm{N}_{\mathrm{K}}-$ К-ий номер 3 порядком 3 гр фи 1 т бл.4 $(K=\overline{1}, \bar{N})$.

- в гр фі 6 з зн ч ються зн чення приросту і, який визн ч ється 3 формулою (2). еобхідно відмітити, що приріст і визн ч ється тільки для термінів служби до відмови, які вк з ні в гр фі 3. кщо терміни служби до відмови повторюються 
послідовно т безперервно, то приріст і в цьому вип дку з лиш ється незмінним. мін приросту відбув ється всякий р 3, коли терміни служби до відмови (гр ф 3 ) перерив ються термін ми служби до цензурув ння $\mathrm{t}_{\mathrm{p}, \mathrm{j}}$, які приведені в гр фі 4.оцінки вірогідності відмов (функції розподілу - $\hat{F}_{i}$ ), які визн ч ється з формулою

$$
\hat{F}_{i}=\frac{m_{i}}{N}
$$

де $\mathrm{m}_{\mathrm{i}}-$ береться 3 гр фи 5 (т бл. 3);

$\mathrm{N}-3$ г льний обсяг вибірки гр фи 1.

- в гр фу 8 з писуються оцінки вірогідності безвідмовної роботи $\hat{P}_{i}$, які чисельно дорівнюють зн ченню величини г м при визн ченні г м відсоткового терміну служби (

$$
\hat{P}_{i}=1-\hat{F}_{i}=\frac{\gamma}{100}
$$

5. підст ві скл дених в рі ційних рядів (т бл. 3) визн ч ється г м -відсотковий термін служби сл, ,j кожного ј-го елемент виробу озброєння з формулою (5)

$$
{ }_{c л, \gamma}={ }_{c л, i}+\frac{\gamma / 100^{-} \hat{i}}{\hat{P}_{i+1}-\hat{P}_{i}}\left(T_{c л, i+1}-{ }_{c л, i}\right)
$$

де сл,і; сл,i+1 - Зн чення терміну служби до відмови (гр ф 3 т бл. 4);

$\hat{P}_{i} ; \hat{P}_{i+1}-$ відповідні зн чення вірогідності $\hat{P}_{i}$.

еличини $\hat{P}_{i}$ т $\hat{P}_{i+1}-$ н йближчі до $\frac{\gamma}{100}$ вірогідності з в рі ційного ряду (т бл. 4) визн ч ються у нерівності

$$
\hat{P}_{i+1} \leq \frac{\gamma}{100} \leq \hat{P}_{i}
$$

6. підст ві відомостей, які зібр ні н ми у вигляді т блиць вир ховується середній ресурс р,ср 3 формулою (6)

$$
\left.\hat{p}_{p, c p}=\sum_{i=1}^{r} T_{p, i}\left[{ }^{(}{ }_{p, i+1}\right)-{ }^{\wedge}\left({ }_{p, i}\right)\right]+\left(1-F_{r}\right) t_{N}
$$

ким чином, пібив ючи підсумки вищез зн ченому з формули (5), ми 6 чимо, що г м -відсотковий термін служби елемент бо окремого виробу н пряму з лежить від терміну служби до відмови, тобто тільки від відпр цюв ння виробом гр ничного ресурсу. рикл д. Озглянемо в рі нТ 3 стосув ння методики визн чення пок зників довговічності т обгрунтуємо гр нично допустимі терміни експлу т ції 100-мм г рм т $\quad-12$ н підст ві н лізу відомостей шодо їх експлу т ції протягом ост нніх 40-45 років.

сновним визн ч льним п р метром, який буде зн чною мірою вплив ти н порядок експлу т ції г рм ти, є знос к н лу ствол . гідно 3 нструкцією по к тегорув нню р кетно- ртилерійського озброєння м ксим льно допустимий знос к н лу ствол не може перевищув ти 3,7 мм. рипустимо, що при перевищенні допустимого зносу к н лу ствол виріб д $€$ відмову при експлу т ції, тобто при н бутті виробом цього гр ничного ст ну неможн г р нтув ти його норм льну роботу. н лізуючи відомості щодо експлу т ції виробів, з повнюємо т блиці із 3 г льними х р ктеристик ми виробів.

икористовуючи формули (1), (2), (3), (4) скл д ємо в рі ційний ряд т з повнюємо н ступну т бл. 6.

підст ві скл деного в рі ційного ряду термінів служби г рм ти -12 т з стосовуючи формулу (5), вир ховуємо $T_{c л, r}$

пок зників т блиці видно, що $\gamma / 100=0,85$ при $0,8<0,85<0,9$.

ким чином

$$
\begin{gathered}
c л, \gamma={ }_{c л, i}+\frac{\gamma / 100-P_{i}}{P_{i+1}-P_{i}}\left(T_{c л, i+1}-{ }_{c л, i}\right)=26+ \\
+\frac{0,85-0,9}{0,8-0,9} \times(26-26)=26+\frac{0,05}{0,1} \times(0)=26 \text { років }
\end{gathered}
$$

н лізуючи вищен ведені розр хунки можн зробити висновок, що гр ничний термін служби г рм т $\quad-12$ зн ходиться у прямій з лежності від н буття ними гр ничного ст ну.

к, тільки при н бутті г рм тою -12 вст новленого гр ничного зносу к н лу ствол можн стверджув ти, що г рм т відпр цюв л вст новлений ресурс експлу т ції.

$$
\text { зв'язку з тим, що г рм т }-12, \text { як }
$$

зн ходиться н зберіг нні, може вичерп ти т кий пок зник, як знос к н лу ствол протягом необмеженої (зн чно перевищуючи вст новлені норм тивною документ цією терміни) кількості років, можн стверджув ти, що строк експлу т ції г рм ти не може обмежув тися ч совими пок зник ми. 


\section{ИсНОВ К И}

озглянут в ст тті методик визн чення пок зників довговічності озброєння дозволяє зробити висновок, що у зр зК х озброєння, ступінь прид тності яких з лежить тільки від гр ничного ст ну, вк з ного в норм тивно-технічній документ ції (зносу к н лу ствол, кількість пострілів тощо), вст новлений норм тивними документ ми гр ничний термін експлу т ції не може бути визн ч льним для прийняття рішення щодо виведення їх з експлу т ції т спис ння.

ким чином озброєння, яке було виведене з експлу т ції тільки н підст ві досягнення ним гр ничного норм тивного терміну експлу т ції, без вр хув ння його технічного ст ну, не може вв ж тися неприд тним для под льшого використ ння т може бути використ но для з безпечення військ.

ж ль, проведені протягом ост нніх років реорг ніз ція т скорочення бройних ил кр їни м ли деякі нег тивні н слідки, вн слідок яких зн чн кількість ще прид тного до використ ння озброєння було безпідст вно виведено з експлу т ції тільки з однією мотив цією відпр цюв нням ним гр нично норм тивного терміну експлу т ції. роблем 3 безпечення військ озброєнням 3 відпр цьов ним гр нично норм тивним терміном експлу т ції в суч сних умов х недост тнього фін нсув ння досить кту льн, тому пит ння використ ння для з безпечення військ цієї к тегорії озброєння потребує под льшого більш поглибленого н лізу т розробки.

\section{писок літер тури}

1. нструкция по $\kappa$ тегориров нию $р$ кетнортиллерийского вооружения. оскв : оенное изд тельство, 1986. - . 6-8.

2. ухнин . . сновы технического обслужив ния и ремонт вооружения. - енз : , 1985. - .2937.

3 озлов . ., ечкин . . беспечение пригодности вооружения и военной техники квосст новлению и ремонту н эт пе их $p$ зр ботки. ртиллерийское и стрелковое вооружение № 4. - иев: ссе, 2007. - 5456.

4. зет «родн рмія» № 73, 21 квітня 2010 року. нтерв'ю іністр оборони кр їни . желя. «кр їнський н род м $е$ бути впевнений, що рмія спромохнн його з хистити».

дійщл доред кції 25.102010 p.

ецензент: к ндид т військових н ук . . роб н, к демія сухопутних військ, ьвів.

\footnotetext{
. . ндреев, . . литич, . . рв нец, . . гд с рян

ссм трив ется методик определения пок з телей долговечности вооружения и ее применение для
} обоснов ния гр ничных норм тивных сроков эксплу $m$ ици вооружения.

лючевые слов : гр ничный норм тивный срок эксплу т ции вооружения, гр ничный норм тивный ресурс вооружения, долговечность вооружения.

\title{
MODERN ASPECTS OF THE APPLICATION OF METHODS FOR DETERMINING INDICATORS OF LONGEVITY FITTINGS TO JUSTIFY THE TIMING OF OPERATION OF ARMS
}

\author{
I. M. Andreev, V. M. Kalytych, Y. V. Varvanets, N. K. Bagdasaran
}

The technique of determining the performance durability of weapons and its application to justify the boundary normative operation of weapons are considered.

Keywords: boundary normative operation of weapons, boundary norativny resource weapons, durability weapons. 